\title{
Brazilian Feminisms in Global Spaces: Beijing and Beijing $+20^{\circ}$
}

\author{
Cecilia M.B. Sardenberg
}

\begin{abstract}
Within the last decades, feminist movements in Brazil have advanced significantly beyond borders, gaining increasing recognition in global spaces, UN ones in particular, for positively influencing Brazil's official position. Unsurprisingly, Brazil has served four terms in the Commission on the Status of Women (CSW) and, in the eyes of more progressive delegations, is a much needed presence to ensure no lost ground on what has been achieved in previous conferences. However, the actual presence of Brazilian feminist activists in the delegations and the NGO Forums has dwindled considerably. What have been the strategies and mechanisms at play in maintaining a radical vein in our official position? Can it be sustained without the more active involvement of feminist activists - say, throughout Brazil's new role as president of the 60th CSW session? These are some of the issues I address in this article, sharing the views of activists present at those events.
\end{abstract}

\section{Introduction}

Nearly $8.00 \mathrm{pm}$ in New York and yet, discussions on 'methodologies' at the Beijing+20 reviews were not waning. On the contrary, they promised to go on throughout the night. At stake was the reaffirmation of women's rights as human rights, expansion of the role of the Commission on the Status of Women (CSW) in implementing the Beijing Platform for Action, and a greater participation of civil society organisations in that process. But to those of us watching the proceedings in that crowded room where even floor space was in dispute and diplomatic language with its subterfuges and euphemisms prevailed - the points of contention were not always too clear. It was evident, however, that there were two contending groups: a conservative one led by the African Confederation, opposing all the proposals, and a much more progressive one defended by representatives of (some) Latin American countries, who took to heart the views of feminist organisations, not letting go until the very last minute.

Just outside the room, members of the two groups nervously waited for the outcome. Tensions had been running high for weeks before the sessions, particularly after it was announced that the Beijing+20 Declaration was to be approved on the first day of the 59th Session of the Commission on the Status of Women in New York, 9-20 March 2015 , without any further input from civil society organisations. To show their discontent with this decision and with an agenda that excluded issues dear to feminist movements, Latin American and Caribbean feminists staged a demonstration at the UN main entrance, wearing tape across their mouths to symbolise their silenced voices. A second demonstration was planned, but was called off following news that, at the very last moment the Brazilian representative had secured at least moderate non-governmental organisation (NGO) participation in CSW future proceedings.

The final agreed document, however, appeased neither of the contending groups. For those of us looking for advancements, it came out as a very bland and conservative instrument, representing a regression in relation to Beijing and current demands of women's movements the world over. It was as we gathered for coffee to reflect on the outcomes of our efforts, that we heard that Brazil would be assuming the presidency of the 60th CSW meetings, and began to wonder: was that to be taken as recognition of Brazil's efforts in advancing the agenda on women's rights in the UN? Or was it just a means of watering down the country's position, radical in Beijing in 1995 and still radical at Beijing+20, by granting it a moderating, and thus toned down, role?

That evening back in my hotel room, I reflected on Beijing achievements and how difficult it has been to sustain them throughout the last two decades. 
I have often heard comments, by some of the same people who praised Beijing, that these global spaces staged by the UN are now 'passé', a 'has-been', as transnational feminisms are articulating spaces of their own without UN tutelage and with more progressive agendas. In the Beijing+ review series, Brazilian feminist participation, both in the official delegations as well as in the civil society forums, has dwindled considerably. I witnessed it myself at the Beijing+15 and Beijing+20 meetings: fewer than a handful of us were there. Nevertheless, it is also true that Brazil's official position at those meetings remained as radical. How can this be explained? What have been the strategies and mechanisms at play in maintaining a radical vein in our official position? Can it be sustained without the more active involvement of feminist activists - say, throughout Brazil's new role as president of the 60th CSW session?

These are some of the questions that I propose to address in this article. In what follows, I re-visit Brazilian feminist activism in Beijing and in the Beijing+ review meetings, focusing on Beijing +20 in particular, looking not only at how we made our presence felt in those spaces, but also at how the outcomes played out in our own struggles at home, sharing the views of activists present at those events. ${ }^{1}$

\section{Brazilian feminisms in global spaces}

Widely regarded as one of the most diversified, influential, and better organised women's movements throughout Latin America (Sternbach et al. 1992), feminist movements in Brazil have advanced significantly beyond borders, gaining increasing recognition in global spaces, UN ones in particular. We were there from the very beginning. Bertha Lutz, who led the campaign for the women's vote in Brazil, was one of only four women who participated in the UN charter meeting in 1945.

It was only, however, in the 1990s that Brazil began to have a more prominent presence in UN global spaces dealing with women's issues (Nicodemos 2005). The military dictators, in power for over 22 years (1964-86), sustained a patriarchal gender order in the country, maintaining that the status of women would automatically improve with economic development. This was the official Brazilian position for the world conferences on women held in Mexico City in 1975, and in Nairobi in 1985 (Saffioti 1995).

The strengthening of the feminist movement at home, part of the process of re-democratisation started in the mid-1980s, brought in time considerable changes in Brazil's official position. Feminists not only joined in the struggle to end the dictatorship, but also mobilised to guarantee women's rights in the design of a new constitution (Sardenberg and Costa 2010, 2014). They supported progressive candidates, thus gaining legitimacy for women's demands within the new governmental circles. As a result of this dialogue, they ensured the creation of special councils for women's rights, police stations for battered women, and more healthcare programmes for women, including the legal abortion services within the public health system (Sardenberg and Costa 2010). ${ }^{2}$

The 1990s were the decade of feminist professionalisation, with the institutionalisation of feminist studies in universities, and the emergence of feminist NGOs (Alvarez 1998). They were characterised by the expansion of feminist ideas among other women's movements, particularly the so-called 'popular movements', contributing to a pluralisation of feminism in Brazil (Sardenberg and Costa 2010, 2014). More importantly, the 1990s were the decade of the UN world conferences, which contributed to the expansion of feminist networks throughout Brazil and to the trans-nationalisation of Brazilian feminisms (Pitanguy 2002).

This process began with preparations for the Earth Summit - the UN Conference on Environment and Development - held in Rio de Janeiro in 1992, where Brazilian feminists participated actively, both in pre-conference as well as Global Forum meetings. They were among the almost 2,000 NGOs present at the World Conference on Human Rights in Vienna in 1993, where they guaranteed various references throughout the final declaration, even a specific article recognising women's rights as an integral part of human rights.

Pre-conference organising was strategic for the 1994 International Conference on Population and Development held in Cairo. Brazilian feminist NGOs brought together more than 300 feminists from different countries to produce a consensus on the recognition of women's reproductive and sexual rights. Close dialogues also took place between feminists and the Brazilian Ministry of Foreign Relations, leading to a progressive stand on the part of the official delegation. Brazil was instrumental in negotiating the more difficult issues in the Cairo Programme of Action, such as those dealing with health and reproductive rights, issues that led to a break within the G-77 group. This break remained at the 1995 Beijing conference, where Brazil, once 
again, advanced a more progressive position towards women's reproductive rights.

\section{Brazilian feminisms and Beijing 1995}

The previous UN conferences contributed to the strengthening of Brazilian feminisms, but it was the Fourth World Conference on Women, that made the greater impact, both at home and abroad. Two different processes were set in motion for Beijing, with intense exchanges between them: a governmental one, with official conferences and reports led by the Ministry of Foreign Relations; and a civil society one, led by the Articulação de Mulheres Brasileiras (AMB), created precisely for organising feminist participation in the overall process (Libardoni 1996).

In preparing Brazil's report to the UN, Itamaraty, Brazil's Diplomatic Agency, created a national committee composed of members of the National Council for the Defence of Women (GNDM) and the National Forum of Presidents of State Councils. They engaged the assistance of academic feminists and those active in NGOs, promoting seminars held in different regions of the country, to which activists were invited to attend. Reports from the seminars were fed into the final document. Although the process did not always run smoothly, it unfolded within an atmosphere of dialogue and collaboration between government and activists, which has characterised their relations on gender and women's issues ever since (Libardoni 1996; Saffioti 1995).

Recognising the need to create spaces of their own, under the slogan 'Beijing is Here', AMB staged a series of events in which close to 800 different women's groups participated across the country (AMB 1995a). This process resulted in the preparation of documents providing evidence of the complex situation of women and the profound social inequality within the country (AMB 1995b). Around 700 women participated in a nationwide event held in Rio in June 1995, which culminated in the approval of a 'Political Declaration' for Beijing. Among other issues, it called for a commitment from Brazil and the international community to sustaining the achievements of previous conferences (Nicodemos 2005; Haddad 2007).

The major preparatory event for Beijing was the 39th CSW session in New York, when the draft of the Beijing Platform for Action (BPfA) was to be finalised. At the parallel NGO Forum, more than 1,400 participants gathered to discuss the document as well as strategies to influence the official meetings.
The final draft, however, remained full of 'brackets', indicating a lack of consensus on a series of important issues (Abramovay 1995). To assure a more cohesive regional effort from across Latin American countries, a meeting held in Santiago, Chile, just prior to Beijing, brought together official delegations to compare the regional document with the final draft BPfA approved at the CSW meetings in New York. Efforts were directed towards erasing most of the brackets at the regional level, with agreement that individual countries would be free to pursue on their own those issues lacking consensus at the Beijing conference (Haddad 2007).

Within the Latin American and Caribbean NGO Forum, a more woven agreement was at work. They had a history of regional exchanges through their famous Encuentros (Sternbach et al. 1992; Alvarez et al. 2003), held every three years, and regional networks campaigning together on issues such as sexual and reproductive rights and violence against women. This contributed towards building a more orchestrated position, such that, despite a relatively small group participating in Beijing (about 2,000 women, 300 of them Brazilians), they could act as a block. Furthermore, under the 'Tent of Diversity', women from the region staged a number of daily activities to exchange experiences (Haddad 2007). One important visit paid to the tent was from the official Brazilian delegation. This showcased prestigious support for the NGO Forum's activities, a gesture which was to be followed by other Latin American delegations.

The official delegation met daily with NGO representatives for briefings about ongoing negotiations and the position Brazil should adopt in them. Among the more polemic points discussed was the incorporation of the concept of gender and of a gender perspective within the BPfA, a concept that was widely rejected by the Vatican and Islamic countries, who also opposed the inclusion of sexual and reproductive rights, particularly the legalisation of abortion on demand (Machado 1996). Along with Brazil, Japan, the United States and the European Union fought for the inclusion of the phrase 'sexual rights of women'; however, conservative forces led by the Vatican put up a strong front. The most they were able to advance was the recognition of the control over sexuality as a human right. The Brazilian delegation argued successfully for the inclusion of points approved in the Cairo conference, but was not able to advance the discussion on the legalisation of voluntary abortion, except for the recommendation that 
member countries review their punitive legislation against women who have had illegal abortions

(Haddad 2007; Nicodemos 2005).

As observed subsequently at Beijing +20 , a polemic also surrounded the spelling out of women's rights as human rights. But in Beijing, the absurdity of the denial of the reaffirmation of this principle led Brazilian diplomat, José Augusto Lindgren Alves, coordinator of the National Committee, to burst out: 'Is there anyone here crazy enough to believe that women's rights are not human rights?' (Haddad 2007: 231). The principle was finally reaffirmed. Likewise, the Brazilian delegation was also credited with bringing recognition to the relevance of women's work, particularly that which is not paid, and most notably, for the inclusion of ethnicity and race as discrimination determinants within the BPfA, an essential step in the fight against social inequalities on ethnicity and racial bases.

\section{From Beijing to Beijing+20}

The BPfA is among the most advanced international documents ever produced on gender justice.

It came as a result of much discussion and negotiation - of real battles, at times. Every five years since, another battle has been fought in order to guarantee that those achievements are not lost. During the Beijing +5 review meetings held in New York City in June 2000, negotiations to ensure a gender perspective in the final document led to the emergence of a new group within the G-77: SLAC (Some Latin American Countries), a group of Latin American countries that has supported a more progressive stance towards women's rights (Corrêa 2000). Responding to pressures from feminist organisations at home, Brazil has taken a leading role within this group.

In preparation for Beijing $+5, \mathrm{AMB}$ initiated discussions on the implementation of the BPfA in Brazil, holding a national meeting in January 1999 to discuss findings. Meanwhile, the government created a National Commission to prepare the official UN report, this time without a closer dialogue with civil society. Yet, women's organisations stood their ground on two important demands: presentation of the official report to the movement; and inclusion of feminist and women's movement representatives in the Brazilian delegation (Sant'Anna 2000). Just before the conference in May 2000, AMB held a national meeting in Paraíba, when they voted on a political declaration - known as 'Carta da Paraíba' - reminding the Brazilian government of its promise to advance the implementation of the BPfA.
Meanwhile, at home, Brazilian feminist organisations brought together more than 2,000 representatives from women's forums and feminist organisations throughout Brazil to meet in Brasilia, just prior to the 2002 presidential elections, to draw up the Feminist Political Platform (PPF), later presented to presidential candidates. Once elected and sworn in, President Lula lived up to his promise, creating the Special Secretariat of Public Policies for Women (SPM) with cabinet status in 2003. He also declared 2004 as 'Women's Year' in Brazil, calling for a National Conference of Public Policies for Women (I CNPM) to be held in Brasilia in June, a process that mobilised nearly 200,000 women around the country in local and state conferences.

Nearly 2,000 delegates selected from these conferences assembled in Brasilia to engage in a dialogue between civil society and governmentfrom the municipal through to federal levels - for the formulation of the First National Plan of Public Policies for Women (I PNPM). A second conference (II CNPM), was held in Brasilia in August 2007, when more than 2,000 delegates from all over the country gathered to evaluate the I PNPM and suggest necessary adjustments. This process set in motion a 'participatory state feminism', that is to say, a state feminism that operates with 'more participatory mechanisms, such as councils and conferences, from the local to the national levels', in the formulation and monitoring of public policies for women (Sardenberg and Costa 2010: 281).

The results of the I CNPM were not available for the Beijing+10 review; nevertheless, SPM organised a one-day seminar in Brasilia, bringing together government officials, representatives of international organisations, experts and feminist activists to discuss advances and challenges in implementing the BPfA. Beijing+10 was the first such meeting in which a Brazilian minister for Public Policies for Women, then Dr Nilcéa Freire, participated. She made a passionate speech on the theme of the Millennium Development Goals (MDGs) and the BPfA, emphasising that whereas the Platform contemplated all the MDGs, the reverse was not true; and a change in that direction was needed.

Despite the proactive participation on the part of the minister, few Brazilian feminists made up the official delegation or took part in the NGOs Forum. A similar situation characterised Brazil's participation in the Beijing+15 review meetings, held as part of the 54th CSW session. More than 8,000 women were there to exchange experiences and evaluate 
'good practices' in the BPfA's implementation, yet very few Brazilian feminists were among their number. They had, of course, been very present at I CNPM and II CNPM, which furnished much of the data for Brazil's Beijing+15 reviews. As such, in her pronouncement at the 54th CSW session in New York, Minister Nilcéa Freire had feminist support when she spoke of the need to culturally deconstruct machismo and discrimination against women. She would also declare that, on hearing the interventions of representatives of the different member states in the meetings, one could be led to believe that gender inequalities were being dismantled. However, she added, it is known that, in practice, the reality is much different; gender equality machineries usually operate with very small budgets and without the political authority or coordinating power needed to bring about desired changes.

Indeed, the tone of those meetings was marked by a world crisis - financial, economic, energetic, climatic - and the effect of shrinking budgets. But the discussions suggested that the BPfA was losing the interest and consideration of member states in favour of the MDGs. Not surprisingly, the Beijing+15 Declaration was regarded by feminist organisations as a 'mere technical instrument', a depoliticised document, lacking input from civil society and, as such, a critical perspective (Garcia Prince 2010).

\section{Beijing+20}

Over the last decade, feminist transnational organisations have expressed concern over Beijing+ review processes, on account of rising conservative forces putting Beijing achievements at risk. As such, when the UN launched a consultation process regarding themes to address and the preferred type of space to review the BPfA - whether a fifth world conference or another Beijing+ review meeting they voted for the 'lesser' of the two risky options, rejecting the proposal for a 'fifth'. In preparation for the battles to come, they prepared a document presented to official delegations and civil society organisations, aimed at guaranteeing the agreements of previous conferences.

This was also the position of Brazilian feminists and one also embraced by SPM, the organ responsible for the formulation of the country's official position on women's issues. Although not a self-declared feminist, Dilma Rousseff, the first woman president of Brazil, appointed Professor Eleonora Menicucci, a staunch feminist, to head SPM, well aware of the new minister's radical views (they are long-time friends having suffered prison together for their participation in underground groups against the military dictatorship). Professor Menicucci has engaged well-known feminists to work with her and sustained a position aligned to feminist organisations. Presiding at the XII Regional Conference, held in Santo Domingo in November 2013, in preparation for Beijing+20, she called for a concerted regional presence, asking Latin American and Caribbean representatives to act as a block in the different international forums, in order to approve agreements, declarations and other international instruments which reinforce the building of more egalitarian societies. She also indicated that the regional report should include previous agreements, in which lesbian, gay, bisexual and transgender (LGBT) rights were defended.

Held as part of the 59th CSW session which met in New York from 9-20 March 2015, the Beijing+20 review brought together close to 11,000 people, gathering the largest number of participants in the Beijing+ series. On Sunday 8 March, participants took to the streets of New York to celebrate International Women's Day, actively voicing their demands to representatives of member states. Yet expectations were not running high. To the contrary, feminists feared a backlash, a tendency established during the previous two CSW sessions, when a conservative front was successful in doing away with the term 'gender' in the declarations. As observed in Beijing, so too in the +20 reviews, the use of the term 'gender', and the notion of women's rights as human rights, rendered the draft review documents full of 'brackets', denoting the lack of consensus provoked by a rise of fundamentalist views around the world.

These views not only brought together strange bedfellows (Russia, the Holy See, Indonesia, Nicaragua and the African Union), but also exerted their tentacles over the United States and the European Union, their representatives choosing to take a non-incisive position at the meetings, probably in fear of conservative forces at home. But even if similar forces have been gaining space in Brazil as well - a problem which kept Professor Menicucci back in Brasilia in support of President Rousseff - there was no backing away on the part of the Brazilian official delegation. On the contrary, SPM's executive secretary, Linda Goulart, remained audacious in her pronouncement at the meetings, declaring that: 'For Brazil, the quest for gender equality and women's empowerment is both a government as well as a state policy. There can be 
no doubt that for Brazil women's rights are human rights' (Goulart 2015, my translation). She also expressed preoccupation with the increasing erosion, year after year, of the consensus and commitment to promote gender equality sealed in Beijing. Referring to the Beijing+20 Declaration, approved on the first day of the 59th CSW, she further declared: 'In a moment such as this in which there should be a deepening of commitments and definition of new goals and forms of partnership and cooperation, we have to limit ourselves to reproducing past agreements. Instead of looking to the future, we, as an international community, have our eyes tied to the reality of the already far away year of 1995.'

Most feminist activists would agree with these observations. At least, this was the mood at the meeting of the Latin American and Caribbean Caucus held on the last week of the CSW/ Beijing+20 session. Those present found the official declaration, approved and published on 9 March 2015 , very weak and without ambition, and they denounced the lack of political space for NGO participation in the CSW process. There was consensus that this lack of dialogue led to the nonrecognition of challenges faced by women the world over and, as such, of the transformative changes needed to fully implement both the BPfA and the MDGs. As Joanne Sandler, former UN Women Executive Officer, declared: 'I can't think of any substantive issues that were advanced by this CSW, other than an overall affirmation of the centrality of gender equality and women's empowerment' (Kosovic 2015).

\section{Final considerations: now and then}

Brazilian feminists who have participated in UN global spaces have been unanimous in recognising their relevance and that of the declarations and conventions they produced to the advancement of women's struggles at home. Indeed, their experiences in these and other transnational spaces introduced new strategies and discourses in national activism, fostering the national agenda (Alvarez 1998, 2000). They have spoken as well of the excitement in taking part in the conferences, as expressed by Ângela Freitas ${ }^{3}$ in an interview, where she compares what was 'then' to what we see 'now':

It was really great, back then it was marvellous! [...] Because we learned a lot, we worked a lot, we wrote a lot, we elaborated arguments for our representatives, because Brazil had a very good delegation back then [...] and it was pleasurable because we saw results! We elaborated documents, arguments, we lobbied and helped with negotiations between governments in the background! It was very enriching [...]. And I learned a lot, I learned how the UN worked, how CEPAL worked, how the country representations worked, what it means to be a delegate from civil society, the type of challenge it poses, because it is different from being a militant [...]. Today, there is a risk of moving backwards in the UN, and there are very, very few Brazilian feminists participating, we are not following up, and we hear that our performance is now very weak, very poor...

This 'now and then' feeling was also expressed by Nilza Iraci: ${ }^{4}$

We continue to lobby against the Holy See defending the lay state. But in the last conference, the Beijing +15 , it was ridiculous. Because before, we had our own stand and would be there lobbying, we had our act. In the last meeting, we sort of lost energy, there was this corridor where we had a computer [...] and what was our strategy? It was to pick up piles of their documents and throw them away, because we did not have a counteroffensive strategy. Because the fundamentalists had a heavy, put together act. They thought of everything. They had Brazilians, Costa Ricans, Norwegians, they were international and had people distributing these very attractive materials, from candy, chocolates, pretty young girls...You know, they changed their strategy, before they had these aweful women pinching you in the hallways. Now they have young girls, happy, with vibrant colour. And then I looked around and we were a very small group from Latin America, with nothing to distribute.

A possible explanation for this seeming current 'lack of interest' in UN global spaces on the part of Brazilian feminists - and thus of their scarce presence in delegations in more recent years - was offered by Guacira Oliveira, an active member of the feminist NGO CFêmea. ${ }^{5}$ She noted that, for a long time, the agendas set by UN conferences and conventions allowed us to move forward with our own national agenda, by making use of these international agreements, signed by Brazil, to demand necessary changes at home. ${ }^{6}$ For instance, the promise to revise punitive legislation on the practice of abortion was very important to us. However, at present, as a result of the strengthening of conservative forces in the international arena, the UN agenda has not moved forward; to the contrary, it has fallen far behind, especially on issues of sexual and reproductive rights. As such, it does not have the capacity to further our struggles at home any longer, although it may remain instrumental to member countries that still have far to go in terms of gender equality. 
Indeed, although we still need to make progress on many issues, particularly in relation to the legalisation of abortion (thus Brazilian feminists' interest in the Cairo+20 and Rio+20 conferences, which ended up being disappointing in this regard), in the last decade, Brazil has made big strides towards building greater gender justice. The Maria da Penha Law, comprehensive legislation to confront domestic violence against women, is a good example. Formulated by a consortium of feminist NGOs with inspiration drawn from UN Platforms for Action and modelled after the Organization of American States Belém do Pará Convention which deals with violence against women, it was sanctioned by President Lula in 2006 and has since been recognised by UN Women as one of the most advanced legislation packages on domestic violence in the world.

Of course, feminist voice in Brazil has not been completely harmonious: contestations within feminisms, and between feminist and other segments

\section{Notes}

* In memory of Ana Alice Costa, whose works on feminisms in Brazil will always remain inspirational to all of us.

1 This article is based on interviews and documentary data, as well as field research on 'Brazilian feminisms in global spaces' conducted over 2008-15, including my participation in the 52nd, 53rd, 54th, 55th, 56th and 59th CSW meetings. This has been made possible through funding from Pathways of Women's Empowerment RPG, the Brazilian National Research Council-CNPq, and UN Women. I would like to thank them, as well as the Brazilian Secretary of Public Policies for Women for granting me membership of the official Brazilian delegation. Special thanks go to Carla Gisele Batista for conducting interviews with Brazilian feminist activists who participated in these conferences, to all of those who granted us the interviews, and to Maria Helena Guimarães and Sheila Rodrigues for transcribing their conversations.

2 Since the 1940s, abortions have been legal in Brazil in two instances: pregnancy resulting from rape, or if pregnancy threatens the life of the mother. of the women's movement, have marked its history in Brazil in the last three decades (Sardenberg and Costa 2014). Nonetheless, the chorus of feminist voices has been loud enough to make itself heard by those responsible for the formulation and defence of foreign policy on gender equality issues in UN global spaces, even when only a few feminists are actually present. As Marcela Nicodemos (2005: 130) notes: 'Since the Beijing Conference, Brazil's delivery during the UN forums have become proactive, reflecting not only demands, but also the achievements of women's movements in Brazil'. Unsurprisingly, Brazil has served four terms in the CSW and, in the eyes of more progressive delegations, is a much needed presence so as to ensure no lost ground on what has been achieved in previous conferences. It is up to us, then, Brazilian feminists, to exert pressure at home so that our representatives presiding at the next CSW sessions will remain true to our ideals.

3 Ângela Freitas is a Brazilian feminist active in the NGO Pagu and AMB. She participated in the Beijing conference, as well as Beijing+5, Cairo+5, Beijing+10, as well as in CEPAL meetings and HIV/AIDS discussions in New York and Mexico City. She was interviewed by Carla Gisele Batista in Rio de Janeiro on 23 June 2011.

4 Nilza Iraci is a Brazilian Feminist active in Geledés, a Black Women's NGO. She has participated in the Beijing and Durban conferences and in several CSW meetings. She was interviewed by Carla Gisele Batista in São Paulo on 10 May 2011.

5 Guacira Oliveira participated in the Rio, Beijing, and Durban conferences and their follow-ups. She was interviewed in Brasilia by Carla Gisele Batista on 9 June 2011.

6 This is what Margaret Keck and Kathryn Sikkink (1998) call the 'boomerang pattern' of influence, explained by Alvarez (2000: 3) as the kind of influence ' $[\ldots]$ whereby transnational coalitions of non-governmental, governmental and intergovernmental actors put pressure on more powerful states and IGOs to bring pressure to bear in turn on a particular government which violates rights or resists the desired policy change'. 


\section{References}

Abramovay, M. (1995) 'Uma Conferência entre Colchetes', Revista Estudos Feministas 3.1: 212-18

Alvarez, S. (2000) 'Translating the Global: Effects of Transnational Organizing on Local Feminist Discourses and Practices in Latin America', Meridians: Feminism, Race, Transnationalism 1.1: 30-1

Alvarez, S. (1998) 'Latin American Feminisms "Go Global": Trends of the 1990s and Challenges for the New Millennium', in S.E. Alvarez, E. Dagnino and A. Escobar (eds), Cultures of Politics, Politics of Cultures, Boulder CO: Westview Press

Alvarez, S.; Friedman, E.; Beckman, E.; Blackwell, M.; Chinchilla, N.; Lebon, N.; Navarro, M. and Tobar, M. (2003) 'Encountering Latin American and Caribbean Feminisms', Signs 28.2: 537-80

AMB (Articulação de Mulheres Brasileiras) (1995a)

'Síntese do Documento das Mulheres Brasileiras', in IV Conferência Mundial das Nações Unidas Sobre a Mulher: Igualdade, Desenvolvimento e Paz-Beijing, September, Rio de Janeiro: AMB

AMB (Articulação de Mulheres Brasileiras) (1995b) 'Avaliação do Fórum de ONGs e da IV Conferência Mundial sobre a Mulher - Beijing 1995', November, mimeo, Rio de Janeiro: AMB

Corrêa, S. (2000) 'Pequim+5: Nem um Passo Atrás', Fornal Fềmea 89, www.cfemea.org. br/index.php?option $=$ com_content\&vi ew $=$ article\&id=263:pequim-5-nem-umpasso-atras\&catid=71:numero-89-junho-de2000\&Itemid=129 (accessed 10 May 2015)

Garcia Prince, E. (2010) 'Beijing+15: 'Antesala de una Va Conferencia Mundial de las Mujers? Perspectivas y Ajustes Necesarios', Beijing+15: Miradas desde el Feminismo, III Tercera Edicion de la Escuela del Pensamiento Feminista

Goulart, L. (2015) Na Comissão Sobre a Situação das Mulheres, Brasil Pede Foco no Futuro, 16 March, www.onumulheres.org.br/noticias/na-comissaosobre-a-situacao-das-mulheres-brasil-pede-focono-futuro (accessed 10 May 2015)

Haddad, T. (2007) 'Diplomacia Pública: A Política Externa Brasileira e as ONGs na Conferência de Beijing (1995)', Masters dissertation, Post-Graduate Programme in International
Relations, Rio de Janeiro: Instituto de Relações Internacionais da PUC-Rio

Keck, M. and Sikkink, K. (1998) Activists Beyond Borders: Advocacy Networks in International Politics, Ithaca NY: Cornell University Press

Kosovic, L. (2015) Joanne Sandler: 'Links between Section $\mathcal{7}$ and Patriarchy need to be High on the Agenda of Feminists Worldwide', interview, 10 April, www.genderit.org/ node/4292 (accessed 28 May 2015)

Libardoni, M. (1996) Avaliação dos Processos de Negociação, Diálogo e Colaboração entre Governo e ONGs nos Processos de Beïing e Pós-Beïing na América Latina e Caribe - Sub-Região Brasil, Brasilia: Fórum de ONGs da América Latina e Caribe com o Apoio do Fundo de Desenvolvimento das Nações Unidas para a Mulher e o Fundo das Nações Unidas Para a Criança

Machado, L.Z. (1996) 'Beijing em Balanço', Revista Estudos Feministas 3.2: 414-26

Nicodemos, M. (2005) As Nações Unidas e a Promoção dos Direitos da Mulher: Retórica ou Realidade? XLVIII, Curso de Altos Estudos (CAE), Brasilia: Instituto Rio Branco, Ministério das Relações Exteriores

Pitanguy, J. (2002) 'Bridging the Local and the Global: Feminism in Brazil and the International Human Rights Agenda', Social Research 69.3: 805-20

Saffiotti, H.I.B. (1995) 'Enfim, Sós: Brasil Rumo a Pequim', Revista Estudos Feministas 3.1: 198-202

Sant'Anna, W. (2000) 'A Caminho de Beijing+5', Proposta 84/85

Sardenberg, C. and Costa, A.A. (2014) 'Feminisms in Brazil: Voicing and Channelling Women's Diverse Demands', in S. Nazneen and M. Sultan (eds), Voicing Demands: Feminist Activism in Transitional Contexts, London: Zed Books

Sardenberg, C. and Costa, A.A. (2010) 'Feminisms in Contemporary Brazil: Advancements, Shortcomings, and Challenges', in A. Basu (ed.), Women's Movements in a Global Era: The Power of Local Feminisms, Boulder CO: Westview Press

Sternbach, N.; Navarro-Aranguren, M.; Chuchryk, P. and Alvarez, S. (1992) 'Feminisms in Latin America: From Bogota to San Bernardo', Signs 17.2: $393-434$ 